ISSN 0258-7122 (Print), 2408-8293 (Online)

Bangladesh J. Agril. Res. 41(1): 67-74, March 2016

\title{
IN VITRO CONSERVATION OF TARO (Colocasia esculenta var. globulifera) AS INFLUENCED BY MANNITOL
}

\author{
M. K. R. BHUIYAN ${ }^{1}$, M. J. HOSSAIN ${ }^{2}$ AND M. M. HAQUE ${ }^{3}$
}

\begin{abstract}
In vitro conservation of germplasm plays a vital role in maintenance breeding and also has many advantages over the conventional system. The experimental results for conservation of Colocasia sp. also proved this. In relation to explants and osmoticum, meristem and axillary bud could be conserved for 24 months while meristem-base died after 6 months. Mannitol as osmoticum @ 4\% performed nicely to conserve Colocasia upto 24 months. Only meristem and axillary bud could be conserved for 24 months with the use of $4 \%$ mannitol. But other level of mannitol remained culture alive for varying periods (6 to 12 months). After 24 months, the plant height was $6.5 \mathrm{~cm}$ for the meristem and 6.4 for axillary bud.
\end{abstract}

Keywords: Colocasia, mannitol, meristem and axillary bud.

\section{Introduction}

Generatively reproduced plants are simply kept for long periods in the form of seed in closed containers or air-tight packets and are stored at low temperature $\left(-18^{\circ} \mathrm{c}\right.$ or lower) and low humidity. Problems occur only when the seeds are viable for short period or in vegetatively propagated plants, the other methods (in vitro) can be adopted in this situation successfully (Pierik, 1987)

Taro is a vegetatively propagated crop; it has traditionally been conserved in field collections. Significant genetic erosion may occur because most of the taro clones are contaminated with endogenous pathogens and under field conditions, reinfections may also occur (Matthews, 2002). The taro corms and cormels have short storage life under natural storage condition (Akhond et al., 1997). Losses may also occur due to natural hazards (drought, flood etc.) and unconscious cultural practices (varietal admixtures). Therefore, it is essential to establish a repository where disease free planting materials can be stored for longer periods.

In vitro system is extremely suitable for storage of plant materials (Hadiuzzaman et al., 1997), since, in principle, it can be stored disease free on a small scale under limited growth conditions (Kartha, 1985). Recently, carnation, strawberry, potato, pea, fruit trees, carrot, ground nut, Prunus, Ipomoea, anthurium, gerbera etc. are stored in vitro of meristems or shoot tip cultures (Pierik, 1987).

Arditti and Strauss (1979) opined that in vitro storage of taro with the minimum growth condition is feasible. Addition of osmotic agents such as sucrose, mannitol

${ }^{1}$ Principal Scientific Officer, TCRC, Bangladesh Agricultural Research Institute (BARI), Gazipur, ${ }^{2}$ Director, TCRC, BARI ,Gazipur, ${ }^{3}$ Senior Scientific Officer, Farm Division, BARI, Gazipur, Bangladesh. 
or sorbitol to the culture medium efficiently reduced growth and extended storage life of many vegetatively propagated crop (Karhu, 1997; Shibli, 1990; Shibli et al., 1992). Many researchers around the world worked on conservation of taro but very scarce. Storage under growth retarding conditions is most suitable for conservation of active collections (Withers, 1980). Slow growth can be achieved by using mannitol (Jarret and Gawel, 1991; Mourai and Maria, 1993).

Though, many of the research on the conservation of taro have been reported but works were mostly done in abroad with exotic varieties. Therefore, to conserve our taro variety for long-term without sub culture, the present study has been undertaken.

\section{Materials and Method}

For conservation of taro an experiment was conducted at tissue culture laboratory of the Tuber Crops Research Centre (TCRC), BARI, Joydebpur, Gazipur. Well sprouted cormels of mukhikachu var. 'Bilashi' (Colocasia esculenta var. globulifera) was used. The axillary bud (ca. $0.2-0.4 \mathrm{~mm}$ ) and meristem (ca. 0.5 $\mathrm{mm}$ ) were excised from sterilized sprout of cormel and used as explant. After excising the meristem remaining meristem base was also used as explant.

The in vitro growing medium contained mineral salts and vitamins (Murashige and Skoog, 1962) plus mannitol according to the treatment. Three types of explants (axillary bud $(\mathrm{Ab})$, meristem $(\mathrm{M})$ and meristem base $(\mathrm{Mb})$ and four levels of mannitol $(0,2,4$ and $6 \%$ ) were used in this experiment. Cultures were maintained under light (16 h photoperiod). Complete Randomized Design (CRD) was followed having five replications each having 5 tubes. The cultured tubes were stored for 24 months. The total number of plants survived at different intervals after in vitro multiplication was recorded. The percent plant survival at 2, 4, 6, 8, 12 and 24 months after in vitro multiplication was calculated by the formula as follows:

$$
\% \text { plant survival }=\frac{\text { Total number of tubes with survived plant }}{\text { Total number of tubes cultured }} \times 100
$$

Plant height at different intervals was measured by destroying the test tube. Data were analyzed statistically and mean separation was done at $1 \%$ level of probability by DMRT.

\section{Results and Discussion}

The results of explants on long term conservation are presented in Fig.1. The survival of explants with time was recorded upto 24 months. After two months about $70.0 \%$ plant of meristem, $52.5 \%$ of axillary bud and $75.0 \%$ of meristem base were survived. These figures were gradually reduced with time. After eight months, no plants derived from meristem-base survived and after 24 months, only 
$20.0 \%$ and $15.0 \%$ plant derived from meristem and axillary bud, respectively found alive. After 8 months all plants derived from meristem-base died because the concentration of the osmoticum used in this experiment might have failed to produce any significant effect. Further investigation may be needed to find out the reasons.

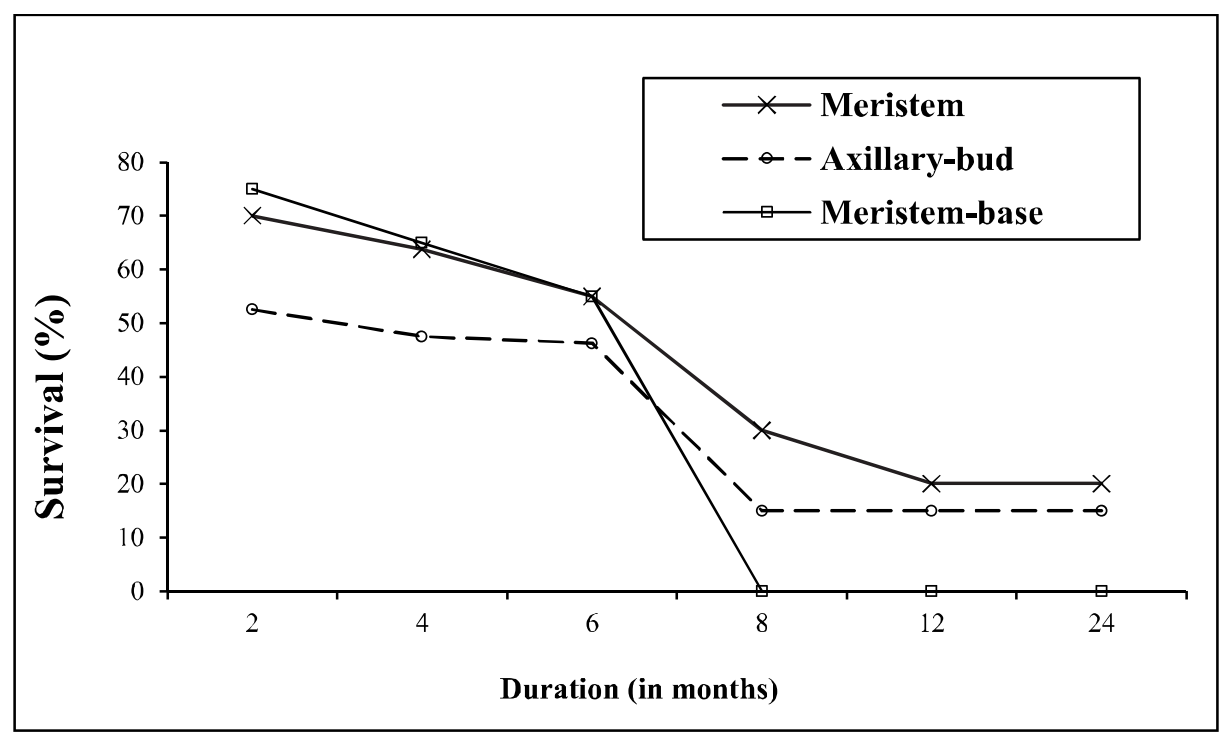

Fig1. Showing effect of explants on survival (\%) of in vitro conserved plants.

Table 1. Main effect of explants on plant height

\begin{tabular}{l|c|c|c|c|c|c}
\hline \multirow{2}{*}{ Explant } & \multicolumn{6}{c}{ Plant height after different months of conservation $(\mathrm{cm})$} \\
\cline { 2 - 7 } & 2 & 4 & 6 & 8 & 12 & 24 \\
\hline Meristem (M) & $2.6 \mathrm{~b}$ & $4.4 \mathrm{~b}$ & $6.8 \mathrm{~b}$ & $4.3 \mathrm{~b}$ & $1.5 \mathrm{a}$ & $1.6 \mathrm{a}$ \\
Axillary bud (Ab) & $2.3 \mathrm{c}$ & $4.5 \mathrm{~b}$ & $6.8 \mathrm{~b}$ & $5.4 \mathrm{a}$ & $1.3 \mathrm{~b}$ & $1.6 \mathrm{a}$ \\
Meristem base (Mb) & $4.5 \mathrm{a}$ & $7.5 \mathrm{a}$ & $12.9 \mathrm{a}$ & $0.0 \mathrm{c}$ & $0.0 \mathrm{c}$ & $0.0 \mathrm{~b}$ \\
\hline
\end{tabular}

In a column, means followed by common letters are not significantly different from each other at $1 \%$ of level of probability by DMRT.

At the same time plant height was measured (Table 1). It was found that plants grew slowly and continued up to 24 months when meristem and axillary bud were used as explants. Whereas plants grew up to 6 months and gained a height up to $12.93 \mathrm{~cm}$ when derived from meristem-base. With advancing of time, the larger leaves became senescence and died; in case of meristem base after 6 months not a single plant remained alive. But In case of meristem and axillary bud, only the central leaves remained alive up to the end of the experiment. The height of which was about $1.60 \mathrm{~cm}$ after 24 month. After eight months the gradual declining of 
plant height was may be due to shortage of osmoticum (Jarret and Gawel, 1991). This finding was in agreement with Mourai and Maria (1993).

Mannitol as a suitable osmoticum keeps plant alive for long with very slow shoot growth. After 2 months, the survival rate was the maximum of $71.7 \%$ at 0 or 2.0 $\%$ mannitol, which reduced gradually with increasing mannitol level. Culture survival rate started reduced from four months. After 8 months, all cultures of 0.0 or $6.0 \%$ mannitol died, which also happened for $2.0 \%$ mannitol after 12 month but about $46.7 \%$ plants with $4.0 \%$ mannitol remained quite alive after 24 months (Fig. 2), which is in accordance with previous by Mourai and Maria (1993).

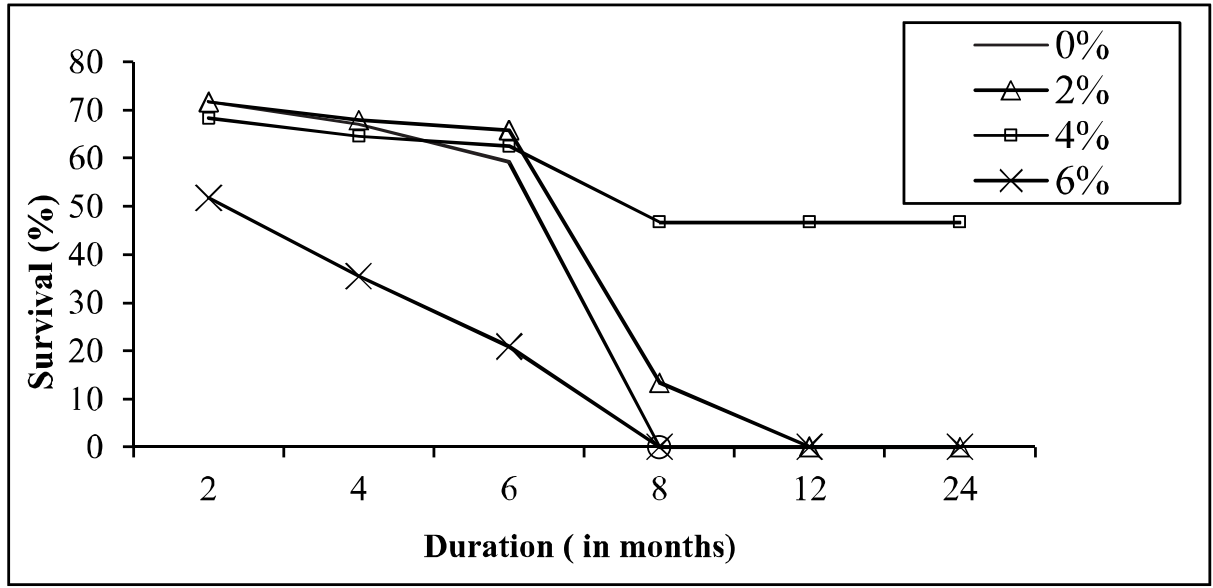

Fig.2. Showing effect of mannitol on survival (\%) of in vitro conserved plants.

Table 2. Main effect of Mannitol on plant height

\begin{tabular}{c|c|c|c|c|c|c}
\hline \multirow{2}{*}{$\begin{array}{c}\text { Mannitol } \\
(\%)\end{array}$} & \multicolumn{5}{|c}{ Plant height after different months of conservation $(\mathrm{cm})$} \\
\cline { 2 - 7 } & 2 & 4 & 6 & 8 & 12 & 24 \\
\hline 0 & $4.5 \mathrm{a}$ & $7.6 \mathrm{a}$ & $12.9 \mathrm{a}$ & $0.0 \mathrm{c}$ & $0.0 \mathrm{~b}$ & $0.0 \mathrm{~b}$ \\
2 & $3.1 \mathrm{~b}$ & $6.3 \mathrm{~b}$ & $10.6 \mathrm{~b}$ & $8.3 \mathrm{a}$ & $0.0 \mathrm{~b}$ & $0.0 \mathrm{~b}$ \\
4 & $3.1 \mathrm{~b}$ & $5.0 \mathrm{c}$ & $7.2 \mathrm{c}$ & $3.4 \mathrm{~b}$ & $3.8 \mathrm{a}$ & $4.3 \mathrm{a}$ \\
6 & $1.7 \mathrm{c}$ & $2.9 \mathrm{~d}$ & $4.6 \mathrm{~d}$ & $0.0 \mathrm{c}$ & $0.0 \mathrm{~b}$ & $0.0 \mathrm{~b}$ \\
\hline
\end{tabular}

In a column, means followed by common letters are not significantly different from each other at $1 \%$ of level of probability by DMRT.

In all the mannitol levels, the plants attained the maximum height after 6 months ranging from $4.6 \mathrm{~cm}$ with $6.0 \%$ mannitol to $12.9 \mathrm{~cm}$ with control. After 8 months all plants derived from 0 and $6.0 \%$ mannitol died. After 12 months all plants died except $4.0 \%$ mannitol. After 24 months, the plants with $4.0 \%$ mannitol had 4.3 $\mathrm{cm}$ in height (Table 2). In the lowest and the highest level of mannitol, plants could not perform well may be due to different osmotic concentration of mannitol. 
At the lowest level there was no osmoticum but at the highest level the concentration of osmoticum was lethal for plant growth or phytotoxic (Bessembinder et al., 1993).

Explants with mannitol levels showed that survival rate was the highest after two months, which became reduced onwards and after 8 months living plants were only obtained for meristem with $2.0 \%$ and $4.0 \%$ mannitol and axillary bud with $4.0 \%$ mannitol. After 24 months, survival plants only found with $4.0 \%$ level of mannitol with meristem and axillary bud (Table 3 ).
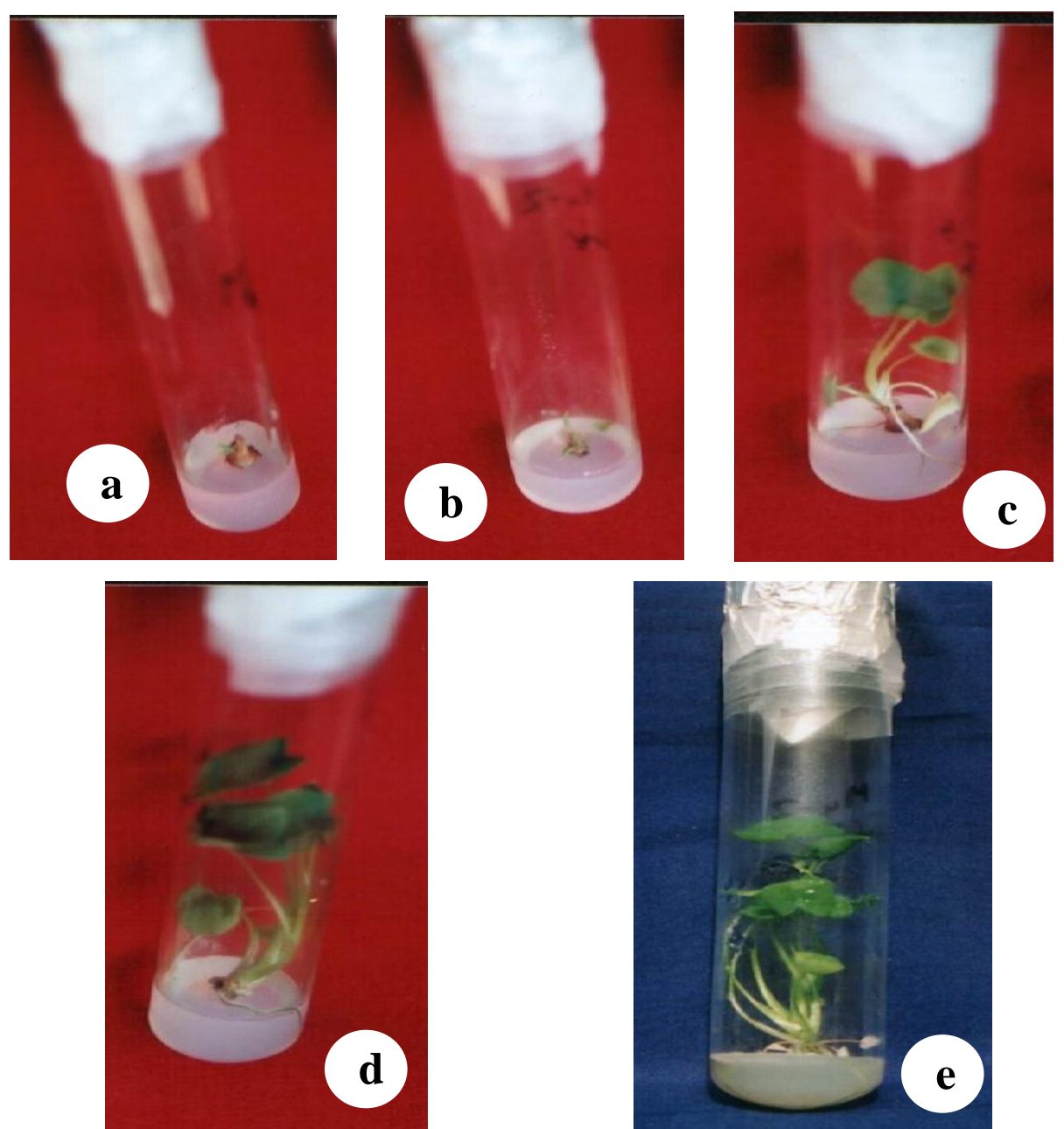

Fig. 3 (a-e). Conserved plants of Colocasia esculenta in $4 \%$ mannitol at different months after culture (a. 2 months after culture, b. 4 months after culture, c. 8 months after culture, d. 12 months after cultue and e. 24 months after culture). 
Table 3. Combined effect of explant and mannitol on survival (\%) of conserved plants

\begin{tabular}{|c|c|c|c|c|c|c|c|}
\hline \multicolumn{2}{|c|}{ Treatment } & \multicolumn{6}{|c|}{ Plant survival(\%) after different months of conservation } \\
\hline Explant & Mannitol (\%) & 2 & 4 & 6 & 8 & 12 & 24 \\
\hline \multirow{4}{*}{ 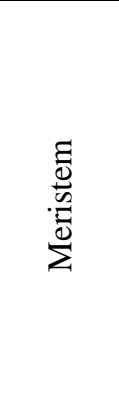 } & 0 & $\begin{array}{c}75.0 \\
(8.7) \mathrm{a}\end{array}$ & $\begin{array}{c}73.7 \\
(8.6) \mathrm{a}\end{array}$ & $\begin{array}{c}57.5 \\
(7.6) \mathrm{bc}\end{array}$ & $0.0 \mathrm{~d}$ & $0.0 \mathrm{c}$ & $0.0 \mathrm{c}$ \\
\hline & 2 & $\begin{array}{c}75.0 \\
(8.7) \mathrm{a}\end{array}$ & $\begin{array}{c}73.7 \\
(8.6) \mathrm{a}\end{array}$ & $\begin{array}{c}73.7 \\
(8.6) \mathrm{a}\end{array}$ & $\begin{array}{c}40.0 \\
(6.3) \mathrm{c}\end{array}$ & $0.0 \mathrm{c}$ & $0.0 \mathrm{c}$ \\
\hline & 4 & $\begin{array}{c}85.0 \\
(9.4) \mathrm{a}\end{array}$ & $\begin{array}{c}83.7 \\
(9.2) \mathrm{a}\end{array}$ & $\begin{array}{c}83.7 \\
(9.2) \mathrm{a}\end{array}$ & $\begin{array}{c}80.0 \\
(9.0) \mathrm{a}\end{array}$ & $\begin{array}{c}80.0 \\
(9.0) \mathrm{a}\end{array}$ & $\begin{array}{c}80.0 \\
(9.0) \mathrm{a}\end{array}$ \\
\hline & 6 & $\begin{array}{c}55.0 \\
(7.4) \mathrm{c}\end{array}$ & $\begin{array}{c}33.7 \\
(5.8) \mathrm{d}\end{array}$ & $\begin{array}{c}7.5 \\
(2.7) \mathrm{d}\end{array}$ & $0.0 \mathrm{~d}$ & $0.0 \mathrm{c}$ & $0.0 \mathrm{c}$ \\
\hline \multirow{4}{*}{ 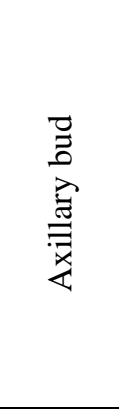 } & 0 & $\begin{array}{c}65.0 \\
(8.1) \mathrm{b}\end{array}$ & $\begin{array}{c}62.5 \\
(7.9) \mathrm{b}\end{array}$ & $\begin{array}{c}62.5 \\
(7.9) b\end{array}$ & $0.0 \mathrm{~d}$ & $0.0 \mathrm{c}$ & $0.0 \mathrm{c}$ \\
\hline & 2 & $\begin{array}{c}65.0 \\
(8.1) \mathrm{b}\end{array}$ & $\begin{array}{c}65.0 \\
(8.1) \mathrm{b}\end{array}$ & $\begin{array}{c}65.0 \\
(8.1) \mathrm{b}\end{array}$ & $0.0 \mathrm{~d}$ & $0.0 \mathrm{c}$ & $0.0 \mathrm{c}$ \\
\hline & 4 & $\begin{array}{c}55.0 \\
(7.4) \mathrm{c}\end{array}$ & $\begin{array}{c}55.0 \\
(7.4) \mathrm{c}\end{array}$ & $\begin{array}{c}55.0 \\
(7.4) \mathrm{c}\end{array}$ & $\begin{array}{c}50.0 \\
(7.1) b\end{array}$ & $\begin{array}{c}50.0 \\
(7.1) b\end{array}$ & $\begin{array}{c}50.0 \\
(7.1) \mathrm{b}\end{array}$ \\
\hline & 6 & $\begin{array}{c}25.0 \\
(5.0) \mathrm{d} \\
\end{array}$ & $\begin{array}{c}7.5 \\
(2.8) \mathrm{e} \\
\end{array}$ & $0.0 \mathrm{~d}$ & $0.0 \mathrm{~d}$ & $0.0 \mathrm{c}$ & $0.0 \mathrm{c}$ \\
\hline \multirow{4}{*}{ 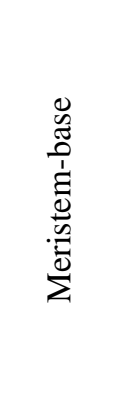 } & 0 & $\begin{array}{c}75.0 \\
(8.7) \mathrm{a}\end{array}$ & $\begin{array}{c}65.0 \\
(8.1) \mathrm{b}\end{array}$ & $\begin{array}{c}55.0 \\
(7.4) \mathrm{c}\end{array}$ & $0.0 \mathrm{~d}$ & $0.0 \mathrm{c}$ & $0.0 \mathrm{c}$ \\
\hline & 2 & $\begin{array}{c}75.0 \\
(8.7) \mathrm{a}\end{array}$ & $\begin{array}{c}65.0 \\
(8.1) \mathrm{b}\end{array}$ & $\begin{array}{c}55.0 \\
(7.4) \mathrm{c}\end{array}$ & $0.0 \mathrm{~d}$ & $0.0 \mathrm{c}$ & $0.0 \mathrm{c}$ \\
\hline & 4 & $\begin{array}{c}75.0 \\
(8.7) \mathrm{a}\end{array}$ & $\begin{array}{c}65.0 \\
(8.1) \mathrm{b}\end{array}$ & $\begin{array}{c}55.0 \\
(7.4) \mathrm{c}\end{array}$ & $0.0 \mathrm{~d}$ & $0.0 \mathrm{c}$ & $0.0 \mathrm{c}$ \\
\hline & 6 & $\begin{array}{c}75.0 \\
(8.7) \mathrm{a}\end{array}$ & $\begin{array}{c}65.00 \\
(8.1) \mathrm{b}\end{array}$ & $\begin{array}{c}55.0 \\
(7.4) \mathrm{c}\end{array}$ & $0.0 \mathrm{~d}$ & $0.0 \mathrm{c}$ & $0.0 \mathrm{c}$ \\
\hline
\end{tabular}

Figures in parenthesis indicate square root transformed data

In a column, means followed by common letters are not significantly different from each other at $1 \%$ of level of probability by DMRT

The plants attained the maximum height after 6 months $(13.0 \mathrm{~cm})$. At this period, all plants of axillary buds died with $6.0 \%$ mannitol. After 8 months all plants from meristem-base and mannitol at 0.0 and $6.0 \%$ died. This might be due to the fact that mannitol failed to work on meristem-base. Mannitol at $0.0 \%$ might be insufficient to act, whereas $6.0 \%$ mannitol might be phytotoxic (Bessembinder et al., 1993). In some cases, the slow growth of plants was observed with $4.0 \%$ mannitol up to 24 months (Table 4), which is an advantage for in vitro conservation of any crop. The result of this experiment was in agreement with the findings of Siddiqui et al. (1996) 
Table 4. Combined effect of explant and mannitol on plant height

\begin{tabular}{|c|c|c|c|c|c|c|c|}
\hline \multicolumn{2}{|c|}{ Treatment } & \multicolumn{6}{|c|}{ Plant height after different months of conservation $(\mathrm{cm})$} \\
\hline Explant & Mannitol (\%) & 2 & 4 & 6 & 8 & 12 & 24 \\
\hline \multirow{4}{*}{ 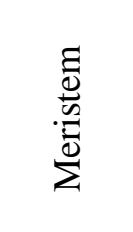 } & 0 & $4.8 \mathrm{a}$ & $7.5 \mathrm{a}$ & $13.0 \mathrm{a}$ & $0.0 \mathrm{e}$ & $0.0 \mathrm{c}$ & $0.0 \mathrm{c}$ \\
\hline & 2 & $2.5 \mathrm{~d}$ & $5.5 \mathrm{c}$ & $8.8 \mathrm{c}$ & $12.0 \mathrm{~b}$ & $0.0 \mathrm{c}$ & $0.0 \mathrm{c}$ \\
\hline & 4 & $2.5 \mathrm{~d}$ & $3.8 \mathrm{~d}$ & $4.5 \mathrm{~d}$ & $5.2 \mathrm{c}$ & $5.8 \mathrm{a}$ & $6.5 \mathrm{a}$ \\
\hline & 6 & $0.6 \mathrm{f}$ & $0.8 \mathrm{e}$ & $1.0 \mathrm{e}$ & $0.0 \mathrm{e}$ & $0.0 \mathrm{c}$ & $0.0 \mathrm{c}$ \\
\hline \multirow{4}{*}{ 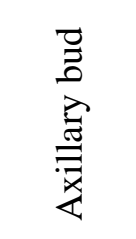 } & 0 & $4.2 \mathrm{c}$ & $7.6 \mathrm{a}$ & $12.8 \mathrm{a}$ & $0.0 \mathrm{e}$ & $0.0 \mathrm{c}$ & $0.0 \mathrm{c}$ \\
\hline & 2 & $2.2 \mathrm{e}$ & $5.8 \mathrm{~b}$ & $10.0 \mathrm{~b}$ & $12.9 \mathrm{a}$ & $0.0 \mathrm{c}$ & $0.0 \mathrm{c}$ \\
\hline & 4 & $2.2 \mathrm{e}$ & $3.7 \mathrm{~d}$ & $4.4 \mathrm{~d}$ & $5.0 \mathrm{~d}$ & $5.6 \mathrm{~b}$ & $6.4 \mathrm{~b}$ \\
\hline & 6 & $0.6 \mathrm{f}$ & $0.7 \mathrm{e}$ & $0.0 \mathrm{f}$ & $0.0 \mathrm{e}$ & $0.0 \mathrm{c}$ & $0.0 \mathrm{c}$ \\
\hline \multirow{4}{*}{ 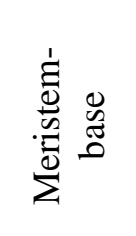 } & 0 & $4.7 \mathrm{ab}$ & $7.6 \mathrm{a}$ & $13.0 \mathrm{a}$ & $0.0 \mathrm{e}$ & $0.0 \mathrm{c}$ & $0.0 \mathrm{c}$ \\
\hline & 2 & $4.5 \mathrm{ab}$ & $7.5 \mathrm{a}$ & $13.0 \mathrm{a}$ & $0.0 \mathrm{e}$ & $0.0 \mathrm{c}$ & $0.0 \mathrm{c}$ \\
\hline & 4 & $4.4 \mathrm{~b}$ & $7.5 \mathrm{a}$ & $12.8 \mathrm{a}$ & $0.0 \mathrm{e}$ & $0.0 \mathrm{c}$ & $0.0 \mathrm{c}$ \\
\hline & 6 & $4.0 \mathrm{c}$ & $7.4 \mathrm{a}$ & $12.9 \mathrm{a}$ & $0.0 \mathrm{e}$ & $0.0 \mathrm{c}$ & $0.0 \mathrm{c}$ \\
\hline
\end{tabular}

In a column, means followed by common letters are not significantly different from each other at $1 \%$ of level of probability by DMRT.

who found that $0.0-3.0 \%$ mannitol had no significant effect on survival percentage of cultures. Bessembinder et al. (1993) found that mannitol concentration of 4.5 to $6.0 \%$ appeared to be lethal which is also in agreement with the findings of the present study.

\section{References}

Akhond, M. A.Y., M. O. Islam and M. Ali. 1997. In vitro conservation of taro (Colocasia esculenta var. antiquorum) under different sucrose levels. Plant Tissue Cult. 7(2): 8188 .

Arditti, J. and M. S. Strauss. 1979. Taro tissue culture manual. South Pacific Commision Information Document No. 44-1979. Noumea, New Caledonia.

Bessembinder J. J. E, G. Staritsky and E. A. Zandvoort. 1993. Long-term in vitro storage of Colocasia esculenta under minimal growth conditions. Plant Cell Tiss. Org. Cult. 33: $121-127$.

Hadiuzzaman, S., M. S. Hossain and A. Habib. 1997. Long-term preservation and maintenance of banana (Musa sapientum var. Sagar) germplasm through in vitro culture. Plant Tissue Cult. 7(2): 103-107.

Jarret. R. L. and N. Gawel. 1991. Chemical and environmental growth regulation of sweet potato (Ipomoea batatas (L.) Lam.) in vitro. Plant Cell Tiss. Org. Cult. 2: 153-160. 
Karhu, S. T. 1997. Sucrose use in relation to shoot induction by sorbitol and cytokinin in apple. J. Amer. Soc. Hort. Sci. 122: 476-480.

Kartha, K. K. 1985. Cryopreservation of plant cells and organs. CRC Press Inc. Boca Raton. USA, Pp. 1-276.

Matthews, P. J. 2002. Taro Storage Systems. In: vegeculture in Eastern Asia and Oceania S. Yoshida and P. J. Matthews ( eds.). The Japan Center for Area Studies, Osaka. Pp. 135-163.

Mourai, I. R. and C. F. Maria. 1993. In vitro Conservation of Colocasia esculenta (L.) Schott germplasm. I Jardim-Museu Agricola Tropical/IICT, Largo dos Jeronimos, 1400-209 Oeiras, Portugal.

Murashige, T. and F. Skoog. 1962. A revised medium for rapid growth and bioassays with tobacco tissue cultures. Physiol. Plant. 15: 473-491.

Pierik, R. L. M. 1987. Storage of plant material in vitro. In: In vitro culture of higher plants. Martinus Nijhoff Publishers, Dordrecht, Pp. 296-300.

Shibli, R. A. 1990. Physiological studies of in vitro water requirements and water relations of Crysanthemum (Crysanthemum morifolium Ramat.), PhD Dissertation, University of Illinois, IL, USA, Pp. 13-18, 44-50.

Shibli, R. A., M. A. L. Smith and L. A. Spomer. 1992. Osmotic adjustment and growth responses of three Crysanthemum (Crysanthemum morifolium Ramat.) cultivars to osmotic stress induced in vitro. J. Plant Nutr. 15: 1373-1381.

Siddiqui, S. U., M. F. Chaudhary and R. Anwar. 1996. Studies on the in vitro conservation of potato (Solanum tuberosum L.) germplasm in Pakistan. Plant Genetic Resource Newsl. 107: 28-30.

Withers, L. A. 1980. Tissue culture storage for genetic conservation. Rep. Int. Board Plant Gen. Res. (IBPGR), FAO, Rome, Pp. 1-91. 